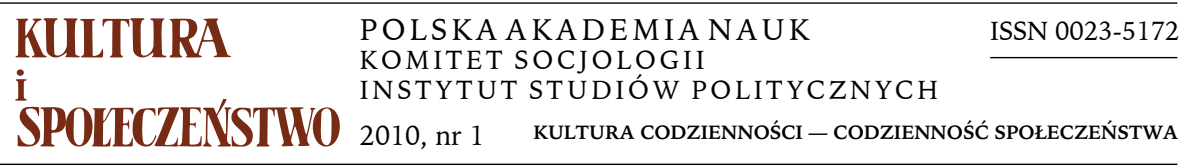

JUSTYNA LASKOWSKA-OTWINOWSKA

Uniwersytet Kardynała Stefana Wyszyńskiego w Warszawie

\title{
PODRÓŻE DO PRACY JAKO ELEMENT NOWEGO STYLU ŻYCIA POSTULATY RUCHU SPOŁECZNEGO SLOW DOWN
}

\author{
„Jeśli możesz zwolnić, kiedy wszyscy wokół popędzają Cię, to \\ jesteś jednym $z$ nas, a nie jednym $z$ nich. Bądź dumny z tego! \\ Co dla nich jest szybkie, dla nas jest wolne, bo jeśli coś jest \\ warte zrobienia, to należy robić to wolno. \\ Niektórzy urodzili się powolnymi - uwierzmy im! \\ Wylegiwanie się w lóżku z poranną filiżanką herbaty to naj- \\ doskonalszy stan dla ludzkości”. \\ Motto ruchu Slow Down (fragment)
}

\section{REFLEKSJE O PRESJI CHWILI I POTRZEBIE SPOWOLNIENIA RYTMU ŻYCIA}

Współczesna kultura kręgu euroamerykańskiego pełna jest różnorodnych zjawisk, które łączy kontestacja dominującego nurtu cywilizacyjnego. Jeden z ciekawszych i coraz szerzej rozlewających się prądów tej krytyki zawiera postulaty spowolnienia rytmu życia. Wynikają one $z$ obawy o skutki wzrostu tempa życia i powiększania się kompresji czasu, co możemy obserwować od drugiej połowy XX wieku. O zmianie podejścia do czasu pisali między innymi James Gleick (2003), Thomas Hylland Eriksen (2003) czy wielokrotnie Zygmunt Bauman ${ }^{1}$. W pracach tych autorzy podejmują kwestię poczucia zagrożenia spowodowanego przyspieszeniem życia, w którym nie mamy już szans na cieszenie się wspomnieniem czy marzeniem. Zagrożeni chwilą żyjemy pod presją hasła epoki, które brzmi: „nie-trać-ani-minuty”. „W istocie nawet «tu i teraz» jest dziś zagrożone, ponieważ następna chwila nadchodzi tak prędko,

Adres do korespondencji: laskowskaotwinowska@gmail.com

${ }^{1} \mathrm{Na}$ temat różnych aspektów podejścia Zygmunta Baumana do czasu zob. Tarkowska 2005. 
że trudno jest przebywać w tej, która jeszcze trwa" (Eriksen 2003, s. 11). Życie „tu i teraz” to, według innej metafory, „obcinanie chwili bieżącej z obu stron" (Bauman 2000, s. 145) - i od strony przeszłości, i od strony przyszłości. Prowadząc swe co najwyżej nomadyczne życie: od jednego do drugiego tak okrojonego epizodu (Bauman 1998, s. 221), gdy napotykamy czas powolny, wpadamy w popłoch. Ów czas powolny, czynności wymagające dłuższego zaangażowania zostają zwyciężone przez czas szybki, nauczyliśmy się bowiem na później odkładać wykonanie prac długoterminowych (Eriksen 2003, s. 211). Społeczeństwo współczesnych bogatych krajów żyje w ciągłej teraźniejszości, w przestrzeni skurczonej przez rozwój środków lokomocji, a czynność czasochłonna postrzegana jest jako ta, która niepotrzebnie chce wypełnić zbyt dużą przestrzeń naszego życia. Staje się więc niebezpiecznym anachronizmem. Już na początku XX wieku Fryderyk Nietzsche (1905, s. 265) zauważał: „Nawet wkrótce dojść może do tego, że się ulegać będzie skłonności do życia kontemplacyjnego (to znaczy przechadzki z myślami i przyjaciółmi) nie bez pogardy dla siebie i nieczystego sumienia". Diagnoza postawiona ostatecznie pod koniec XX wieku wywołała refleksję nad potrzebą poszukiwania metod ochrony czasu powolnego.

W zbiór działań, które należy podjąć, aby zapobiec skutkom pośpiechu, wpisują się propozycje biorące początek od ruchu Slow Food, już rozpoznanego i spopularyzowanego przez mass media. Powstał on jako sprzeciw wobec rozprzestrzeniania się tak zwanych fast foodów, czyli jadłodajni typu McDonald czy Burger King, których „filozofia” najpełniej zostaje oddana w ich nazwie — „szybkie jedzenie”. Pierwszy oddział organizacji Slow Food w 1986 r. założył dziennikarz radiowy i smakosz Carlo Petrini - na znak protestu przeciw otwarciu w sercu Rzymu, przy Schodach Hiszpańskich punktu McDonald, co uznał za obrazę wartości związanych z włoską kulturą stołu. Oprócz sprzeciwu koncepcja Slow Food zawierała też przesłanki konstruktywne, dzięki którym rozpowszechniła się jako ruch wspierający regionalne, tradycyjne i uzyskiwane naturalnymi metodami, czyli bez chemicznych dodatków, produkty spożywcze, a także zanikającą kulturę biesiadowania. Trzy lata po słynnym proteście Petriniego ruch wyszedł poza Włochy - delegaci z piętnastu krajów podpisali w Paryżu Manifest Międzynarodowego Ruchu dla Ochrony Prawa do Przyjemności. Obecnie Slow Food liczy 86 tysięcy członków w stu krajach i stał się bardzo popularny. Możemy o nim czytać także w polskiej prasie codziennej: „Mają własne restauracje, sklepy, uczelnię [w 2004 r. w ramach organizacji Slow Food powstał Uniwersytet Nauk Gastronomicznych w Pollenzo w Piemoncie - J. L.-O.] i wydawnictwo. Co roku dziesiątki tysięcy smakoszy spotyka się w październiku na Salonie Smaku w Turynie, wielkich targach regionalnej żywności. Slow Food stał się marką rozpoznawalną na całym świecie i prestiżową. Logo ślimaka to marzenie wielu producentów żywności - w Polsce może się nim pochwalić między innymi oscypek” — pisze w „Gazecie Wyborczej” o Slow Food Julia Pańków (2009, s. 46). 
W latach dziewięćdziesiątych XX wieku na wzór Slow Food zaczęły pojawiać się przedsięwzięcia społeczne o podobnym przesłaniu, które współcześnie mieszczą się pod jednym szyldem Slow Movement. Należy do nich ruch Cittaslow. Podobnie jak Slow Food, także ten ruch narodził się we Włoszech. W 1999 r. burmistrzowie kilku włoskich miasteczek postanowili bronić jakości życia i lokalnego kolorytu, tak jak dziesięć lat wcześniej Carlo Petrini bronił jakości jedzenia. Obecnie międzynarodowa sieć Cittaslow skupia kilkadziesiąt ośrodków z czternastu krajów, między innymi Włoch, Anglii, Norwegii, Australii, Korei Południowej, Niemiec i Polski. O dostęp do sieci może starać się miasto, które ma nie więcej niż 50 tysięcy mieszkańców, może się poszczycić cennymi zabytkami, oryginalną, tradycyjną lokalną kuchnią i kultywowane jest w nim regionalne rzemiosło. Musi też spełniać 55 innych, wymienionych w manifeście kryteriów dotyczących ochrony środowiska, przyjaznej ludziom przestrzeni miejskiej, wspierania tradycyjnego rzemiosła i oczywiście lokalnych produktów. „Idealne powolne miasteczko to takie, w którym ulice zamknięte są dla samochodów, nie ma w nim supermarketów, sieciowych sklepów ani fast foodów, śmieci są segregowane, niepełnosprawni mogą wszędzie dotrzeć, a lokalne produkty są chronione" (Pańków 2009, s. 47). Pierwszym polskim "powolnym" miastem stał się w 2007 r. Reszel, po nim do sieci przystąpiły kolejne trzy: Lidzbark Warmiński, Biskupiec i Bisztynek.

Do Slow Movement ${ }^{2}$, zwanego też ruchem Slow Down, należą takie przedsięwzięcia, jak Simply Life - ruch antykonsumerystyczny, nawołujący do zmiany stylu życia, uproszczenia go i świadomego zubożenia, przy jednoczesnym nastawieniu na rozwój wewnętrzny, bardziej autentyczny, skierowany ku przeżywaniu procesu życia bezpośrednio, bez wyolbrzymionej konsumpcji dóbr. Osiągnięciem tego ruchu jest ustanowienie $w$ wielu krajach inicjatywy społecznej zwanej Dniem Bez Zakupów. Akcja jest propagowana przez niektóre władze lokalne. Do ideologii Simply Life należy też dieta wegańska, życie bez telewizji, pozyskiwanie pożywienia $z$ własnych upraw. Aby realizować te postulaty, zwolennicy Simply Life decydują się na zmianę miejsca zamieszkania, przenoszą się z dużych miast do małych lub nawet na wieś. Do ruchu należą też takie odmiany działań, jak Slow Design. Oto przykład: „Na każdy sweter potrzeba wełny z jednej owcy. Każda owca ma imię. Holenderska projektantka Christien Meindertsma robi swetry tylko z wełny zwierząt, które poznała osobiście. Do swetra dołącza jego biogram ze zdjęciem i informacją o zdobytych przez nie nagrodach" (Pańków 2009, s. 47).

Ponadto mamy Slow Travel - głoszący ideę odmasowienia turystyki, ale też propagujący realnie powolne podróżowanie, na przykład na słoniu. Obok Simply Life mamy też Slow Life, którego propagatorzy mówią, że jest to styl życia realizowany metodą budowania $\mathrm{w}$ życiu związków $z \ldots$ życiem, powią-

\footnotetext{
2 Zob.: www.slowmovement.com
} 
zania nas samych z tym, co robimy, z ludźmi, których spotykamy na swej drodze, miejscami czy pożywieniem, poprzez powolną kontemplację własnego życia. Uczestnicy tego "plemienia" 3 powołują się na zapomniany raj kultur tradycyjnych, które były właśnie, według nich, kulturami związków: dużych rodzin, własnego, powoli produkowanego pożywienia i silnych społeczności lokalnych ${ }^{4}$.

Ruch Slow Life sformułował dziesięć własnych Slow Rights, wśród których znajdujemy hasła:

— każdy ma prawo żyć powoli,

— nikt nie musi żyć $\mathrm{w}$ więzieniu pośpiechu,

— nikt nie może być zmuszany do konsumeryzmu,

— każdy ma prawo do poszukiwania i życia według zasady conviviality, czyli autonomii i wspólnotowości jednocześnie ${ }^{5}$.

Pod koniec 2008 r. ukazała się w Polsce bodaj pierwsza książka autorstwa przedstawiciela tego ruchu, założyciela i głównego redaktora pisma „The Idler”, pod znamiennym tytułem Jak być leniwym. Tom Hodgkinson podpowiada w niej, jak prowadzić życie w duchu Slow Life: „W próżnowaniu chodzi o wolność, i to nie wolność wyboru między MacDonaldem a Burger Kingiem czy Volvo a Saabem. Chodzi o wolność wyboru życia, jakie się chce prowadzić, z dala od szefów, pensji, dojazdów, zakupów i długów" - pisze o jednej z pozornych wolności konsumpcjonizmu: wolności wyboru produktu (Hodgkinson 2008, s. 9).

Hodgkison walczy w swej książce $z$ „przesądami”: przesądem konieczności wczesnego wstawania ${ }^{6}$, pełnoetatowego zatrudnienia i robienia kariery. W za-

\footnotetext{
3 W znaczeniu, który współcześnie nadaje temu pojęciu Michel Maffesoli (2008).

${ }^{4}$ To w kulturach tradycyjnych ujawnia się pełny wymiar biesiadowania, postulowanego przez założycieli Slow Food i znajdującego swoje miejsce w koncepcji Slow Life. W tych kulturach bowiem ów całościowy wymiar wspólnotowy wykracza poza świat żywych. Kreowaniu wspólnoty ze zmarłymi służą uczty cmentarne, powszechne między innymi u Romów czy w obrządku prawosławnym.

5 Dochodzi tu, jak sądzę, do zbitki dwóch znaczeń słowa conviviality: pierwszego, encyklopedycznego, które wywiedzione $z$ łaciny znaczenie angielskie łączy z biesiadowaniem, przebywaniem razem $z$ innymi, oraz drugiego, które zostało rozszerzone przez znanego pisarza kontrkulturowego Ivana Illicha. „Wybrałem termin «conviviality» — pisze on — żeby zaznaczyć opozycję wobec przemysłowego pojęcia "produktywność». Moje określenie ma oznaczać autonomiczny i kreatywny sposób obcowania wzajemnego różnych osób oraz człowieka ze środowiskiem. Ma też być opozycyjne do postawy warunkowanej oczekiwaniami innych oraz wymuszanej przez środowisko stworzone przez człowieka. Obmyśliłem pojęcie "conviviality» opisujące indywidualną wolność realizującą się we współzależności jednostek i jako wyraz uniwersalnych wartości. Jestem przekonany, że w każdym społeczeństwie, w którym "conviviality" zostało zredukowane poniżej pewnego stopnia, produkcja przemysłowa nigdy nie jest $\mathrm{w}$ stanie satysfakcjonująco zaspokoić potrzeb członków społeczeństwa" (Illich 1973, rozdz. 2 [www.opencollector.org/history/homebrew/tools.html]). Dodajmy, że oddziały Slow Food noszą nazwę właśnie covivium.

${ }^{6}$ Autor krytykuje takie opinie jak siedemnastowieczny pogląd, że konieczność wczesnego kładzenia się spać i wczesnego wstawania to remedium na przestępczość, gdyż nie pozwala na nocne hulanki (Hodgkinson 2008, s. 18).
} 
mian proponuje prawdziwe slow life: wylegiwanie się w łóżku do południa, gdyż tego wymaga kreatywność: „Aby mieć pomysły i wiedzieć, jak je zrealizować twierdzi - potrzeba czasu do namysłu, $z$ dala od biurka, telefonu i problemów dnia codziennego. Poranna drzemka to najlepsza pora" (Hodgkinson 2008, s. 23). Hasło porzucenia pełnego etatu na rzecz zajmowania się ulubionymi czynnościami w czasie wolnym sięga czasów kontrkultury lat sześćdziesiątych $\mathrm{XX}$ wieku ${ }^{7}$. Miało też kontynuację $\mathrm{w}$ tak zwanym Pokoleniu X, subkulturze lat osiemdziesiątych XX wieku. Jak widać, w krajach zamożnego Zachodu jest ono na tyle atrakcyjne, że podnosi je kolejnie pokolenie: „ustawiczne zapracowanie [...] jest symptomem upośledzonej żywotności, zaś zdolność do próżnowania oznacza wszechstronny apetyt i mocne poczucie własnej wartości" (Hodgkinson, 2008, cyt. wyd, s. 354); Hodgkinson cytuje też klasyków z XVIII i XIX wieku, takich jak Robert Stevenson czy Paul Lafarque: „Jeśli chcemy w naszej cywilizowanej Europie odnaleźć ślady naturalnej ludzkiej piękności, należy jej szukać u ludów, których gospodarcze przesądy nie wykorzeniły jeszcze nienawiści do pracy" (Lafarque 1961, s. 4). Cóż zatem robić, aby odzyskać to stracone piękno życia? „[...] idźcie w ślady tych dzielnych prekursorów próżnowania, którzy uczestnicząc $\mathrm{w}$ autentycznym ruchu społecznym, wybierają pracę tylko przez trzy dni w tygodniu" - nawołuje propagator leniwego stylu życia (Hodgkinson 2008, s. 42). Kontrkulturowe przewartościowanie czasu pracy i czasu wolnego (zob. Laskowska-Otwinowska 2008, s. 151-173) oraz eksponowanie koncepcji alienacji pracy także znajdują odbicie w cytowanych poglądach: „Czas to nie pieniądz. Praca i czas wolny mogą się znów połączyć [...]. Czas przejąć kontrolę i przywrócić szczęśliwą harmonię pomiędzy pracą a życiem" (Hodgkinson 2008, s. 42).

Do innych zajęć obowiązkowych współczesnego zacnego obywatela krainy pieczonych gołąbków należą: długie i obfite biesiadowanie w doborowym towarzystwie, długa rekonwalescencja po przebytych chorobach, przywrócenie rangi zwyczajowi picia popołudniowej herbaty oraz pierwszego, wieczornego drinka. Należy też łowić ryby, chodzić do pubu z przyjaciółmi, prowadzić ciekawe konwersacje, kontemplować gwiazdy i księżyc, wyjeżdżać na długie wakacje. Mile widziane jest też urządzanie imprez we własnym domu, palenie tytoniu, upijanie się i rozrabianie, nie mówiąc już o seksie. Można się w tej chwili zaśmiać, ale apel ten jest swoistym zjawiskiem kultury, które ma też dużo poważniejsze konotacje. Należy do nich aktywność zwana Slow Parents - postulat działania edukacyjnego mającego uwrażliwić rodziców na w pełni zaangażowany proces wychowywania dzieci. Jest też Slow Read, w nazwie wykorzystujący kontrast do popularnych kursów szybkiego czytania. Jego istotą okazuje się postulat epistemologiczno-etyczny, w myśl którego jedynym ratunkiem dla rozpędzonej cywilizacji jest powrót do czytania głęboko rozumiejącego, medytacyjnego,

\footnotetext{
7 Pisałam o tym w innym miejscu (Laskowska-Otwinowska 2008, s. 162-164).
} 
gdyż charakterystyczne dla współczesności powierzchowne czytanie, z nastawieniem na szybką przeróbkę informacji jest, po pierwsze, źródłem dyslekcji u dzieci, a po drugie, przyczyną upadku zasad demokracji wśród dorosłych (Pullman 2004). Wolne, rozumiejące czytanie dla współczesnego świata powinno stać się rodzajem biblioterapii, także politycznej.

Spróbujmy więc potraktować poważnie ruch Slow Down, wraz z jego naczelnym hasłem: „Do less, slowly”, z jego stroną internetową, której nazwę można przetłumaczyć jako „Instytut Międzynarodowego Nierobienia za Dużo”, oraz innymi zawołaniami typu: „Wielozadaniowość to słabość moralna” lub nakazami częstego ziewania i kultywowania marzeń, zamiast ambicji. Przeplatanie wątków poważnych i groteskowych jest przecież zabiegiem charakterystycznym dla wystąpień postmodernistycznych, które same z siebie starają się zrobić paszkwil ${ }^{8}$. Ruch Slow Down wydaje się bowiem autentyczną odpowiedzią na narastającą we współczesnym świecie obawę.

\section{VITA ACTIVA, VITA CONTEMPLATIVA, VITA MEDITATIVA}

Wśród najczęściej wspominanych przez różnych autorów metod spowolnienia znajdują się medytacja lub kontemplacja (zob. np. Nowotny 1994; Gleick 2003; Hodgkinson 2008). Świetnie pasują one do leniwego stylu życia: „Dusza próżniaka potrzebuje kontemplacji i zamiast czynnego wypoczynku albo imprezy marzy mu się, że siedzi w pawilonie na wzgórzu, gdzieś w Chinach $z$ długą brodą i mądrym uśmiechem, rozmyślając nad pięknem przyrody i szaleństwami natury ludzkiej" (Hodgkinson 2008, s. 177). Czyż nie trafia ten cytat w marzenia większości z nas? Jeśli o mnie chodzi, to wszystko w tym obrazku, prócz długiej brody, bardzo mi pasuje! Jednak znalezienie wolnej chwili na kontemplację czy medytację nie jest dziś łatwe. Na cóż jednak mamy specjalistów od Slow Life?! Potrafią oni wskazać, gdzie możemy schwytać odpowiednie momenty. Hodgkinson (2008, s. 268) optuje za łowieniem ryb, oglądaniem gwiazd, długimi podróżami pociągiem czy staniem w ulicznym korku.

Również podróże samochodowe to dla Hodgkinsona (2008, s. 268) czas, w którym puste chwile można zamienić „w rozkosznie zamyśloną bezczynność". Jako działanie mogące spowolnić bieg życia co najmniej stukilometrowy

8 Jak pisze Ewa Nowina-Sroczyńska (2007 s. 176) w odniesieniu do najnowszych działań formacji artystycznej Łódź Kaliska: „Podstawową kategorią opisującą i interpretującą współczesny świat $[. .$.$] jest groteska, ale nie ta spod znaku realizmu groteskowego Bachtina (krytycy nazywają ją$ karnawałowa), lecz współczesne jej rozumienie. Jako kategoria estetyczna nie jest tylko artystyczną procedurą, kryje się za nią mniej lub bardziej wyrazista koncepcja świata, a także apel poprzez negację do dominującej świadomości społecznej. Groteska pokazuje komplikacje i «drugie strony zjawisk», nigdy nie ma charakteru apologetycznego, jest przejawem krytycyzmu i niezależności, a jej strukturalna cecha to ujawnianie zawodności naszej orientacji w świecie. Wszyscy badacze groteski podkreślają, że rozkwita w czasach kryzysu, przemiany, niespójności systemów ideologicznych i estetycznych". 
dojazd do pracy popularyzował Eriksen (2003, s. 220-221): „Istnieją czynności, które z reguły kojarzą nam się z szybkością (lub życzeniem szybkości), a które warto by zdefiniować na nowo jako powolne [...]". Jednak niepokój i zniecierpliwienie, odbierające nam nomen omen „drogocenne [podkr. J. L.-O.] chwile wolne w drodze do pracy", możemy zastąpić — postuluje dalej Eriksen — zmianą świadomości, w której nowym kształcie ujrzymy siebie jako siedzących w samochodzie „z wyłączonym telefonem i radiem”. James Gleick zaś woli podróżować z włączoną muzyką, dzięki czemu można odrobić zaległości w kontemplowaniu ulubionych utworów muzyki dawnej, skomponowanej dla słuchaczy dysponujących dłuższymi momentami czasu wolnego. Jak postuluje Gleick, symbole i gadżety cywilizacji pośpiechu: wszelkiego rodzaju piloty, klawisze szybkiego wybierania numerów, internet $\mathrm{w}$ telefonie komórkowym, i im podobne wynalazki służące zapchaniu każdej chwili niepotrzebną nam treścią, muszą znaleźć swe odpowiedniki wśród czynności, dzięki którym możemy zakosztować odpoczynku i kontemplacji. Dlatego podróżowanie, także to do pracy, powinno stać się rodzajem sztuki ${ }^{9}$, performansem, jak chce Tim Edensor (2001), lub dziełem sztuki kontemplacyjnej. Również cytowany przez Hodgkinsona (2008, s. 49) współczesny pisarz i filozof angielski Will Self zachwala długie podróże samochodem jako metodę odzyskiwania czasu leniwego. Także podróże pociągiem, chociaż dają możliwość podejmowania wielu czynności, przez przedstawicieli ruchu Slow Movement są traktowane jako sprzyjające kontemplacji na równi z monofunkcyjną podróżą samochodem.

Tematów poruszanych przez przedstawicieli ruchu Slow Down jest dość wiele. Wybrałam przykład dojazdów do pracy ze względu na własne doświadczenia w tym zakresie. Postulat wprowadzenia do życia elementów kontemplacji mimo pozornej nowości mieści się w bardzo starym nurcie kultury europejskiej: opozycji między vita activa a vita contemplativa. To wątek europejskiej filozofii i moralistyki, nurt refleksji stale obecny w naszej cywilizacji. Był tematem dyskusji między Abelardem a Bernardem z Clairvaux, ale pojawiał się też znacznie później, na przykład u Auguste’a Comte’a. Obecnie powraca niespodziewanie $\mathrm{w}$ innym kontekście - jako odpowiedź na niepokoje wywołane współcześnie zbyt aktywnym stylem życia. W renesansie, także polskim, korzeniem dyskusji, wówczas religijnej, był podział na twórczość doskonalącą świat i samodoskonalącą, a więc kulturę przedmiotową versus podmiotową. Część uważała kulturę przedmiotową za niższą, służącą jedynie przetrwaniu i odpowiadającą zwierzęcym cechom człowieka, podczas gdy kultura podmiotowa miała za cel zwracanie człowieka ku Bogu. Vite activa jawiło się jako wynikające $z$ cielesnych pożądań, a więc niegodne człowieka, w przeciwieństwie do uduchowionej kontemplacji, do której zaliczono działalność naukową i artystyczną. Dawne koncepcje poszukiwania wiedzy poprzez kontemplację mówią

${ }^{9}$ Polemizuję w tym miejscu z Judith Adler (1989), która uznała, że podróż do pracy czy podróż służbowa nie może być sztuką. 
też o podróżowaniu w celu jej zdobycia. Postawa podmiotowa, uważano, może wznieść człowieka na wyższy poziom egzystencji, upodobnić go do Boga, co jest równoznaczne $z$ osiągnięciem ideału człowieczeństwa. Stąd wzięła początek koncepcja wyższości życia kontemplacyjnego nad życiem praktycznym. Część pisarzy renesansowych uważała, że nie ma mowy o doskonaleniu świata - boskiego dzieła. Można go jedynie kontemplować, a przez to poznawać Boga. Poznanie przez kontemplację jako dążenie do najwyższego poznania samego Boga miało być ponadto źródłem prawdziwego szczęścia. Jak twierdzi Jan Czerkawski (1992, s. 25) koncepcje te są efektem oddziaływania dwóch nurtów w nauce chrześcijańskiej tamtych czasów: manicheizmu i pelagianizmu, czyli idei wyzwolenia poprzez poznanie od zła pozostającego w ciągłej walce $z$ dobrem i koncepcji uwolnienia od grzechu pierworodnego dzięki wolnej woli (szerzej zob. Czerkawski 1992, s. 4, 41).

Powolny, kontemplacyjny tryb życia uwzględniał czas otium, czyli uprawiania nauki lub sztuki, bądź innego pożytecznego zajęcia, co wynikało $z$,pańskiej postawy niezależności, z osobistej i nie nakazanej inicjatywy [rozwijanej-J. L.-O.] w owym szczególnie cennym, własnym i swobodnym wymiarze czasu" (Otwinowska 1980, s. 172; zob. też Laskowska-Otwinowska 2008, s. 159). Otium to także czas rozrywki, na przykład spędzany w dobrym towarzystwie przy biesiadnym stole, a stąd już tylko maleńki krok do współczesnych postulatów ruch Slow Down.

Zaznaczmy jednak, że średniowieczne czy renesansowe pojęcie kontemplacji obejmowało przede wszystkim działania intelektualne. Znaczenia pochodzących z łaciny słów „kontemplacja” i „medytacja” zazębiają się. Contemplatio, contemplationis to: widok; celowanie; kontemplacja; rozmyślanie; rozważanie; studiowanie; medytacja; branie pod uwagę; branie pod uwagę/ze względu na coś, a meditatio, meditationis — rozmyślanie; rozważanie; medytacja; przygotowanie; ćwiczenie. Również we współczesnym, popularnym języku kontemplacja jest bliska medytacji, rozumianej jednak odmiennie - jako funkcja pozaintelektualna, oddawanie się biernej, niewartościującej obserwacji świata zewnętrznego i wewnętrznego. To przesunięcie znaczenia wynika zapewne $z$ asymilacji pojęcia medytacji z filozoficzno-religijnych koncepcji Dalekiego Wschodu.

Takim stanom bliska jest koncepcja nierealności świata przemierzanego podczas podróży, która pojawia się też w dziełach współczesnej kultury, zarówno literackich, jak i filmowych - w tak zwanych filmach i literaturze drogi. W okresie kontrkultury twórcy przyswoili kulturze euroamerykańskiej medytacyjne znaczenie podróży. Spośród znaczących dzieł należy wymienić Zen i sztukę obsługi motocykla Roberta Pirsiga, który opisuje podróż jako rodzaj medytacji według japońskiej szkoły buddyzmu Zen: ,jedziemy dalej pustą drogą. Niczego nie żądam od tych prerii, nie chcę ich fotografować, nie chcę przez nie przejeżdżać. Po prostu są, a my jedziemy" (Pirsig 1999, s. 46). Podróż zatem to czas refleksji bez chcenia i bez świadomości czasu - moment medytacyjny. Dzieła literackie współczesności, oddziałując na kolejne pokolenia, budują me- 
dytacyjno-kontemplacyjne wzorce wyobrażeniowe dotyczące podróży i czynią z niej - paradoksalnie, gdyż cechą współczesnej podróży jest przecież szybkość - jedno $z$ narzędzi zwolnienia rytmu życia. Obecnie koncepcja taka jest odnoszona do podróży w ogóle, w tym podróży do pracy, które zaczynają jawić się, obok innych propagowanych w tym względzie rodzajów aktywności, jako pola walki o spowolnienie rytmu życia.

\section{KONTEMPLOWANIE PODRÓŻY}

Moim głównym celem jest tu ukazanie nowej koncepcji dojazdów do pracy i jej związków z postulatami spowolnienia rytmu życia, jednak przyjrzenie się zagadnieniu tych podróży pod innym kątem może też ujawnić pewne ważne cechy przemiany kulturowej. Podróże do pracy to obecnie prężnie rozwijająca się gałąź biznesu. To całkiem nowe ujęcie doczekało się wyodrębnienia i specjalnego opracowania w literaturze o przemyśle turystycznym, w której wszelkie rodzaje podróży związanych $z$ wykonywaną pracą obejmuje się wspólną nazwą podróży służbowych. Do kategorii tej należą: podróże do pracy, turystyka biznesowa, turystyka konferencyjna i turystyka motywacyjna, czyli wyjazdy będące nagrodą oraz turystyka korporacyjna. Wszystkie te typy podróży mają łączyć się z jakąś formą relaksu i rekreacji, przy czym, ze względu na współczynnik przyjemności są klasyfikowane od najprzyjemniejszych: konferencji, wystaw i targów, do indywidualnych podróży do pracy i seminariów doszkalających, zawierających najmniejszy element rozrywki (Davidson, Cope 2003, s. 240). Podróże służbowe zostały zatem przeniesione $z$ działu „praca” do działu "przyjemność", co jest zgodne z ogólną tendencją przemian cywilizacji euroamerykańskiej, polegającą na przewartościowaniu związku pojęć „praca” — „czas wolny”. Towarzyszą jej też inne metamorfozy, które z czasu wolnego uczyniły czas przyjemności ${ }^{10}$.

Podczas pracy nad zagadnieniem zamieszkiwania na terenach wiejskich w oddaleniu od miejsca pracy (Laskowska-Otwinowska 2009) w artykule Michaela Steinbuscha Miasto na wsi (2006, s. 15) natknęłam się na znamienne sformułowania dotyczące potrzeby życia „na skraju”, „które współgra z pragnieniem wyruszenia gdzieś daleko oraz możliwością codziennego pokonywania odległości”. Cytowany tam respondent poruszał dwa aspekty podróżowania, zaznaczmy, będącego codziennym dojazdem do pracy: kwestię potrzeby podróżowania oraz założenie, że czynność ta wiąże się z przyjemnością. Czy rzeczywiście dojazd do pracy łączy się współcześnie z odczuwaniem przyjemności? Przede wszystkim zadałam to pytanie sobie - jako osobie spędzającej wiele czasu w podróżach do pracy. Według mojego doświadczenia, kilka godzin przymusowo spędzonych pozornie bezczynnie może dawać przyjemność,

10 Tym aspektem czasu wolnego nie będę się tu zajmowała. Pisał o tym Krzysztof Podemski (2004, s. 9), a także cytowany przez niego Chris Rojek (1985). 
tak jak chcą członkowie ruchu Slow Down i inni krytycy kompresji czasu, pod warunkiem, że potraktuje się je jako czas kontemplacji. Jest to jednak kontemplacja, można by rzec, medytująca, która ma więcej cech bierności niż rozrywki intelektualnej $\mathrm{w}$ rozumieniu poprzednich epok. Czas ten nie może też być udręką podróży w zatłoczonym autobusie, na stojąco! Mowa raczej o podróżach klasy średniej, prywatnymi autami. Tyle introspekcja.

John Urry, budując w latach dziewięćdziesiątych XX wieku swą koncepcję podróżowania, skupił się na spostrzeżeniowej funkcji podróży. Zauważył, że współcześnie podróżowanie zmieniło swój cel — zamiast aktywnej produkcji intelektualnego dyskursu w zetknięciu z nieznanym stało się biernym kolekcjonowaniem obserwacji przesuwających się przed oczami podróżującego. Choć koncepcja Urry'ego (1995) dotyczy turystyki, a nie podróży do pracy, zwracam na nią uwagę, gdyż od jakiegoś czasu badacze dostrzegają zacieranie się granic między turystyką a nie-turystyką: „Turystyczne spojrzenie przestaje być domeną turystyki. Rozprzestrzeniło się, stało się często nieodróżnialne od innych sfer życia. [...] Przeciwstawienie turystyki i rutyny życia codziennego staje się coraz mniej uprawnione" (Podemski 2004, s. 85). Stwierdzenie to ukazuje wspólnotę percepcji świata w sytuacji codziennej i niecodziennej oraz to, że wspólnota ta wyrasta $z$ ujednoliconego doświadczenia.

Nowy sposób percepcji ma swoją historię. Owe przechadzki „od niechcenia” jako pierwszy opisał Walter Benjamin (2006). „Ten typ spacerowania, jakby posiadło się «cały czas świata», «jest przeciwieństwem liczenia czasu, tayloryzmu, procesu produkcji [...] przypatrywanie się, dociekanie i marzenia wyróżniały flaneura z zagonionego tłumu" (Game 1991, s. 150). Dostrzeżony w początkach XX wieku paryski flâneur stał się figurą-znakiem, który opisuje pewną formację kulturową: „wszystko widzący, ale sam nie widziany” (Urry 1995, s. 18), niegdyś ukryty w tłumie, dziś za szybą samochodu poddający się kontemplacji postrzeganego świata. Jednocześnie nowy typ postrzegania został wyznaczony przez wynalazek kolei, którą Urry $(2009$, s. 84$)$ uznaje za pramacierz nowych postaci mobilności ${ }^{11}$ : „wraz $z$ nią maszyna stała się pierwszoplanową bohaterką codziennego życia ludzi poza miejscem pracy". Wizualne doświadczenie podróży koleją jest wcześniejsze niż doświadczenie podróży samochodem. Urry opisuje je jako „spłaszczenie i ujarzmienie” oraz „panoramiczne” widzenie krajobrazu. Nie zapominajmy też o jego biernym charakterze.

Współczesne doświadczenie patrzenia, zgodnie z hipotezą jedności percepcji codziennej i niecodziennej, wydaje się bazą dla podróżniczej kontemplacji. Anna Zeidler-Janiszewska (2006) opisuje to doświadczenie przez ana-

11 To wraz z koleją pierwszy raz pojawiła się diagnoza kompresji czasu. Urry (1995, s. 157), przywołuje wypowiedzi z końca XIX wieku: „[cała ludność] zbliżyła się do siebie o jedną trzecią czasu [...]. Jeśli odległość nadal byłaby w ten sposób unicestwiana, wówczas powierzchnia kraju niejako kurczyłaby się, aż okazałaby się niewiele większa niż jedno wielkie miasto". Zob. też: Schivelbusch 1986, s. 34. 
logię do zrekonstruowanego przez Manfreda Sommera sposobu postrzegania we wczesnych formach organizacji społecznej. Jego zdaniem, rodzaj patrzenia, który miałby być charakterystyczny dla społeczności zbieracko-łowieckich, można scharakteryzować jako bezwiedne, mimowolne gromadzenie spostrzeżeń i przeżyć, rodzaj wzrokowego collectio: „[...] «Doświadczenie» collectio, takich przeżyć, jako proces nie jest celowym działaniem, lecz biernym dzianiem się" (Sommer, 2003, s. 331). Rozwijając tę myśl Zeidler-Janiszewska (2006, s. 25) konkluduje: „I nam się czasem także ten rodzaj doświadczenia przydarza, jednak w przeciwieństwie do historycznego łowcy i zbieracza - w sposób wolny i świadomy pozwalamy nań niejako, a czasem go nawet pragniemy". Owo pragnienie bierze się ze zmęczenia koniecznością aktywnego życia, które można opisać jako: „powiązanie ruchu ciała z ruchliwością umysłu. [...] stałe dla nowego, miejskiego doświadczenia w epoce nowoczesności. [...] Świadomość ukształtowana przez nowoczesność ma zmienną, ruchliwą, relatywną strukturę" (Nieszczerzewska 2006, s. 414-415). W takich warunkach naturalną potrzebą staje się wyciszenie i skupienie. Możemy pragnąć stanu bezcelowej, spokojnej kontemplacji, by dać upust naszej leniwej, prawdziwej naturze, choćby podczas krótkich momentów dnia zwanych „turystycznymi minimami”, takich jak śniadanie w ogrodzie czy spacer po parku. Badacze zmian w pojmowaniu turystyki spotykają się tu ze zwolennikami powolnego życia i wskazują na te same sytuacje jako kluczowe dla obu sfer, jednocześnie podkreślając ich wspólny, przyjemnościowy charakter. Piewcą „minimalizmu turystycznego”, czy raczej w tym przypadku urlopowego, jest też Hodgkinson (2008, s. 306), który w ten sposób zachwala uroki mieszkania na wsi: „Pracuję rano, a urlop mam po południu". W podróżowaniu aspekt przyjemnościowy zaznacza się w takim stopniu, że Urry (1995) ukuł dlań nazwę „hedonizmu imaginacyjnego". Składa się nań także estetyzacja podróżowania, która wzmacnia nowy sposób patrzenia: „długotrwałego, kontemplacyjnego, przebiegającego pole widzenia z pewną wyniosłością i niezależnością, w spokojnych interwałach" (Urry 2009, s. 123; por. Taylor 1994, s. 13).

Podsumujmy - nowy sposób patrzenia ma następujące cechy: jest bierny i wyprowadzony poza nurt czasu, zdystansowany, spłaszczony i panoramiczny ${ }^{12}$, czyli patrzymy nie skupiając się na szczegółach, znajdujemy się przy tym w sytuacji odpoczynku, zmiany i przyjemności. Ten rodzaj widzenia może wiązać się z podróżą. Część opisanych cech to elementy kontemplacji. Proponuję zatem rozszerzyć określenie Sommera także na przeżywanie podróży, w tym dojazdów do pracy, a całość tego typu percepcji określić mianem collectio.

\footnotetext{
12 John Urry (2009, s. 93), opisuje za Jeanem Baudrillardem (1998, s. 134) i Alexandrem Wilsonem (1992), jak w Stanach Zjednoczonych dopasowywano krajobraz wzdłuż drogi szybkiego ruchu do potrzeby przeżywania horyzontalnej pustki jako widoku kojarzącego się z wypoczynkiem, „przyjemnego dla oka”.
} 
Rafał Prinke (2007, s. 114) zestawia ze sobą dwa naukowe podejścia do podróżowania. Pierwsze, zaprezentowane przez Deana MacCanella w 1976 r., W słynnej książkę Turysta. Nowa teoria klasy próżniaczej (2005), stało się niejako kanonem dla wielu badaczy piszących o podróżowaniu. Turystyka została przezeń zdefiniowana jako nowa forma kolonizacji świata. Według drugiego stanowiska, podróże osadza się w kontekście rytualnego kontaktu z sacrum. Anna Wieczorkiewicz (1996, s. 62), rozpatrując literackie funkcje wędrowania, obok nawiązania fabuły czy opowiadania o emocjach wymienia budowanie obrazów poszukiwania świętości czy wewnętrznej przemiany. Podróż to czas poza czasem, w którym w kontakcie $z$ odmiennością dokonuje się zmiana podróżnika w nowego człowieka, podobnie jak podczas kontaktów ze świętością. Najpełniejsze połączenie podróży i sacrum to oczywiście pielgrzymowanie ${ }^{13}$.

Podróż do pracy ma wymiar małej transformacji: jest czasem między domem a pracą zawodową, dwoma miejscami, gdzie człowiek ma różne statusy. Jazda we własnym samochodzie umożliwia płynne przemieszczanie się z domu poza dom (Urry 2008) i, oczywiście, z powrotem, gdy po całym, nużącym dniu wracamy do domu przypięci pasami bezpieczeństwa, jak niegdyś Ulisses linami do masztu okrętu, by nie dać się zwieść syrenim głosom pokus. Na podróż służbową można spojrzeć także jak na czas swoistego wyłączenia, „bycia poza", zarówno poza obrębem reguł domowych, jak i zasad panujących w pracy. To czas na zachowania szczególne, wyzwalające nas spod presji chwili. Czas, w którym współczesny, zabiegany kierowca może pozwolić sobie na odrobinę kontemplacji.

\section{CZAS I PRZESTRZEŃ W PODRÓŻY SŁUŻBOWEJ}

Specyfika podróży służbowej własnym autem wynika $z$ tego, w jaki sposób postrzegamy przestrzeń $\mathrm{w}$ trakcie podróżowania. Przede wszystkim warto zwrócić uwagę na pewne charakterystyczne, pogłębiające się cechy traktowania przestrzeni samego samochodu jako „udomowionej”. Jest to zjawisko o dużo szerszym zasięgu. Mówimy na przykład o „udomowieniu” odbioru kultury za sprawą domowych mass mediów. Samochód dołączył do tego stadka współczesnych zwierząt domowych - staje się coraz bardziej „udomowionym” rumakiem dla współczesnych jeźdźców, miejscem na randki, łazienką, w której kończy się poranne golenie i makijaż, szafą przewożącą zmianę ubrań. Auto jest obecnie - jak pisze Urry (2008) - najważniejszym, poza domem, artykułem konsumpcyjnym. Posiadanie go jest składnikiem „dobrego życia”. Ponieważ podróże są coraz ważniejsze dla utrzymania się i coraz dłuższe, samochód staje się miejscem „nie-nieruchomego” zamieszkiwania. Jednocześnie auto jest źródłem

\footnotetext{
13 Pielgrzymowaniem zajmować się tu nie będę. Pisali o nim m.in. Victor i Edith Turner (1978). Także w polskiej literaturze występuje pielgrzym jako jedna $z$ topicznych figur rozważań o wędrowaniu od czasów średniowiecza; zob. Abramowska 1978; Wieczorkiewicz 1996.
} 
wolności, nawet w tym sensie, że: „autem można się wybrać w drogę późno, a nawet zbyt późno" (Urry 2008, s. 414). Wydaje się, że określenie dwelling in - travelling, odnoszone do form długotrwałej turystyki, pasuje również do „zadomowionej” podróży samochodem do pracy. Samochód jest „domem poza domem" (Urry 2008, s. 424), ponieważ umożliwia domowy sposób życia ${ }^{14}$.

„Wędrowanie (wraz ze swą opozycją — trwaniem w miejscu) należy do najstarszych "dwuplanowych» obrazów poetyckich służących przekazywaniu treści antropologii filozoficznej i etyki" (Abramowska 1978, s. 127). Współcześnie, za sprawą podróży służbowych prywatnymi samochodami, które stanowią przedłużenie domu, opozycja ta ulega modyfikacji. Mimo że podróżujemy, jeszcze przez chwilę pozostajemy w domu: w sytuacji osobistej, a nawet intymnej. Dlaczego więc samochód nie miałby obecnie stać się również prywatną „,́́wiątynią dumania”? Przecież: „, [...] najbardziej uderzającą cechą sposobu, w jaki człowiek pojmuje przestrzeń w swoim świecie, jest fakt, że nigdy nie ogranicza on tej przestrzeni do praktycznego poziomu działania i doświadczeń zmysłowych" (Hallowell 1955, s. 187; por. Wieczorkiewicz 1996, s. 8). Koncepcja drogi odzwierciedla stan istnienia człowieka $\mathrm{w}$ świecie. Zmiana sposobu pojmowania podróży świadczy o istotnych cechach wrażliwości w danej epoce. Dlatego przestrzeń podróży do pracy — jako współcześnie znaczących, powszechnych obszarów pośpiechu - zostaje aksjologicznie „zagospodarowana” przez kontestatorów cywilizacji i włączona w obręb ideologii leniwego stylu życia.

Wraz ze zmianą koncepcji podróży manipulacjom znaczeniowym podlega też czas jej trwania. Czas dojazdu do pracy to - według wypowiedzi przedstawicieli ruchu Slow Down - pole ścierania się z siłą dotąd niespotykaną potrzeby opóźnienia i wyprzedzenia zdarzeń zarazem (zob. Gurvitch 1969; por. Tarkowska 1987, s. 107). Kierowca przemieszczając się w dużym tempie, starając się zdążyć na czas do swych obowiązków, jednocześnie pragnie spowolnić swój subiektywny czas przez kontemplację otoczenia i własnego życia. Możliwość subiektywnego zwalniania i przyspieszania czasu została rozpoznana na gruncie teorii językoznawczych przez Andrzeja Łydę (2005). Punktem wyjścia jego rozważań jest stwierdzenie psychologa Jamesa Gibsona (1975), że czas to tylko ruch jaźni w nieruchomym otoczeniu. Łyda opisuje dwa podejścia do czasu. Pierwsze mówi o ruchomym ego w nieruchomym czasie, ego przemieszczającym się z przeszłości w przyszłość. W tym chronocentrycznym ujęciu używamy takich zwrotów, jak: „po nocy jest dzień”. Drugie podejście, w którym możliwe jest manipulowanie czasem, mówi właśnie o nieruchomym ego i poruszającym się czasie, który oddziałuje na ego. Odpowiada to takim zwrotom

14 John Urry (2009, s. 86-87) dostrzega wiele jeszcze niedostatecznie rozpoznanych przez socjologię znaczeń kulturowych samochodu jako „hybrydowego, społeczno-technicznego systemu”. „Znaczenie samochodu polega na tym, że - jak stwierdza - przeprojektowuje społeczeństwo obywatelskie, wprowadzając odmienne sposoby zamieszkiwania, podróżowania i stowarzyszania się w zmotoryzowanej czasoprzestrzeni". 
językowym jak: „najgorsze przed nami”, „w ubiegłym roku” czy „nadchodzące lata” (Łyda 2005, s. 76). Odczuwając czas jako formę aktywną wobec nas, jesteśmy uwrażliwieni na spowolnianie i przyspieszanie czasu, a nawet możemy się zatrzymać w jego strumieniu. W jego, dodajmy, pędzącym dziś strumieniu. I to właśnie owo zatrzymanie, gdy „czas stanął”, jest podstawą medytacji, która — jak sądzę - ukształtowała współczesne rozumienie kontemplacji podróży.

Droga jest też symbolem wolności. To właśnie ta jej cecha spowodowała zainteresowanie tematem podróży w okresie kontrkultury — formacji kulturowej, w której szczególną uwagę udzielano idei wolności. Niekiedy to poczucie wolności $\mathrm{w}$ podróży może niebezpiecznie ześliznąć się $\mathrm{w}$ stronę ucieczki od rutyny i stabilizacji, a nawet od własnej tożsamości. Ta uległość wobec niebezpiecznych syrenich zawołań znajduje odzwierciedlenie również we współczesnej literaturze i filmie drogi, które odtworzyły się w nowym kształcie. Czasami opór wobec pokusy wolności wydaje się nie do przezwyciężenia: „Wyruszając w drogę człowiek otwiera się na nowe wrażliwości [...]. "Droga» pierwotnie przymus i konieczność - staje się wyzwoleniem i otwarciem [...]. Widziany $z$ tej perspektywy wędrowiec-włóczęga stanowi hipostazę snu o wolności. [...] «Droga» szelmy stanowi okres tymczasowej wolności i w jej ramach angażuje grę przypadku i zmienności, wymagając od uczestnika postawy otwarcia, żywego, spontanicznego udziału w bogactwie świata i czerpania $z$ tego satysfakcji" (Wieczorkiewicz 1996, s. 156). Ruch Slow Down głoszący radowanie się bogactwem życia $\mathrm{w}$ takim stopniu, w jakim jest to możliwe, również mocno podkreśla znaczenie wolności. Ciekawe jest zresztą, że ruch o tak hedonistycznych implikacjach deklaruje się jako antykonsumpcyjny!

Odłóżmy jednak na bok szczególne przypadki buntu, impulsy zmiany tożsamości, spontaniczne ucieczki od rutyny i wróćmy do zwyczajnych „uczestników ruchu" podróży do pracy. Podróże te odbywają się zarówno w przestrzeni, jak i w czasie. Kategorie te są misternie powiązane we wzorach społecznych. „Czas nie płynie jednolicie, ma okresy puste, momenty krytyczne i okresy pełne wydarzeń; jest więc to czas nieciągły, [...] nie jest pustym upływem, lecz społecznie oddziałującym czynnikiem, wpływającym na zachowania ludzi, skłaniającym do pewnych działań" (Tarkowska 1987, s. 101). Czas podróży do pracy jest $z$ tego punktu widzenia bardzo ważny, gdyż wyznacza rytm dni i tygodni, na wzór czasu religijnego. Według przytaczanej przez Elżbietę Tarkowską (1987, s. 50) koncepcji Henriego Huberta, czas dojazdów do pracy w społecznym rozumieniu jest czymś na kształt rytuału. Ale jest też przerwą w normalnie toczącym się życiu społecznym. To moment samotności poza stale angażującym nas w pracy i domu społeczeństwem, oddziałującym na nas poprzez podstawowe formy mikrostrukturalne - relacje zawodowe i rodzinne. Podziały czasu i przestrzeni mają bowiem, w myśl tradycji durkheimowskiej, charakter społeczny. Te same jednostki czasu mogą być odczuwane lub/i pojmowane niekoniecznie jako równe: „każdy rodzaj struktury społecznej inaczej wartościuje różne obszary czasu” (Tarkowska 1987, s. 66), a „poczucie czasu człowieka wywodzi 
się z jego miejsca w strukturze społecznej" (Tarkowska 1987, s. 154). Można nawet powiedzieć, że życie społeczne przebiega w różnych czasach.

$\mathrm{Na}$ społeczne znaczenie czasu nakłada się również uspołecznione znaczenie techniki: „Związki społeczne społeczeństwa obywatelskiego wzmacniane są przez techniki ruchu, które dosłownie i wyobrażeniowo łączą ludzi na wielkich, uwarstwionych w złożony sposób, heterogenicznych dystansach. Te wielorakie więzi społeczne - życia rodzinnego, wspólnotowego, wypoczynku, przyjemności ruchu itd. - splatają się w złożonych fluktuacjach czasu i przestrzeni, które nie tylko wiążą się z podróżami samochodowymi, lecz są wręcz $\mathrm{W}$ nich konieczne. [...] Znaczna część życia społecznego nie mogłaby się toczyć bez elastyczności właściwej samochodom" (Urry 2009, s. 89).

Te refleksje o nowym sposobie postrzegania czasu podróży do pracy odnoszą się przede wszystkim do konkretnej warstwy społecznej, nie zaś do zjawiska powszechnego, podobnie jak różnią się między sobą warunki dojazdów do pracy warstw ubogich pracowników fizycznych i zamożnej warstwy menadżerskiej, grupy, którą Tarkowska (1987, s. 107) określa — za Gurvitchem — jako tę o „dominującej aktywności ekonomicznej”. Jeżeli jednak przychylimy się do stwierdzenia, że współcześnie klasyczne determinacje natury społecznej tracą moc ${ }^{15}$, podczas gdy w ich miejsce wynurzają się urynkowione wzorce stylów życia, to postulat spowolniania rytmu życia, a w szczególności kontemplowania podróży do pracy, może mieć szerszy zasięg społeczny. Nawoływania do zmiany stylu życia mają bowiem demokratyczny charakter i kierowane są do wszystkich. Zmiany takie ograniczone są jedynie dostępnością środków wymaganych przez dany styl. Szerszy kontekst koncepcji podróży pozwala wziąć pod uwagę w badaniach dodatkowe aspekty, na przykład kwestię „wieloumiejscowienia” uczestnika podróży czy rozumienie praktyki „dobrego życia” 16. Według niektórych badaczy, różnorodna oferta stylów życia obejmuje również postulat kontestacji zastanych rozwiązań kulturowych: „Stylowi życia w kulturze indywidualizmu można przypisać dwa znaczenia — środka autoekspresji oraz sposobu wyzwalania się jednostki z doświadczanych przez nią opresji i ograniczeń. [...] Znaczenie, jakie przypisuje się stylowi życia, zdaje się rosnąć zwłaszcza wobec stwierdzonej «niefunkcjonalności» tradycyjnie przynajmniej pojmowanej tożsamości" (Jacyno 2007, s. 56-58) ${ }^{17}$. Analiza postulatów ruchu Slow Down pozwala obserwować, jak kształtuje się, rozwija i rozprzestrzenia kolejna propozycja stylu życia. To osobny temat na ciekawe badania.

15 „Wydaje się, że dzisiaj więcej ludzi skłonnych jest podzielać wiarę w zły przepływ chi niż w strukturalne bezrobocie" - pisze na temat zanikania tradycyjnych odniesień społecznych Małgorzata Jacyno (2007, s. 13).

16 Takie tematy badawcze dotyczące dojazdów do pracy zaproponował Gerd Vonderach (2006, s. 28).

17 Przywołuje się w tym kontekście także opinie Petera Bergera, Roberta Bellaha, Anthony’ego Giddensa, Johna Urry'ego, Scotta Lasha i Roberta Wuthnowa. 
Apele o spowolnienie rytmu życia są powszechne, trzeba jednak przyznać, że praktykowanie kierowanych do nas zaleceń nie jest równie łatwe dla wszystkich. Wystarczy choćby spróbować zastosować postulat pracy tylko przez trzy dni w tygodniu do mieszkańców krajów mniej zamożnych niż kraje Europy Zachodniej. Nierówność zasobów uwzględniał w swych rozważaniach Urry, stosując do opisu kultury metaforę przepływów. Ma ona równie dobre zastosowanie przy opisie podróży do pracy przedstawicieli grup dominujących ekonomicznie: „W efekcie tworzą się nowe nierówności przepływu, które kształtują się jako "tunele», w odróżnieniu od nierówności zastoju [...] zachodzi tutaj odkształcenie czasu i przestrzeni ${ }^{18}$ poprzez nowoczesne struktury telekomunikacyjne i transportowe, gdyż przenośniki omijają pewne obszary, a łączą inne obszary "tunelami» bogatej informacji i transportu" (Urry 2009, s. 57). Możemy uznać - choć brzmi to jak stwierdzenie rodem z literatury science fiction - że podróżujący do pracy, w zespoleniu ze swoimi pojazdami-przenośnikami, stają się takimi właśnie „tunelami” przepływu informacji i bogactwa, na czas „przepływu” wyłączającymi się z ogólnej sieci, by zaznać chwili błogosławionego, wewnętrznego zastoju. Ale tylko wtedy, gdy wezmą sobie do serca postulat spowolnienia rytmu życia, który proponuje ruch Slow Down.

\section{BIBLIOGRAFIA}

Abramowska Janina, 1978, Peregrynacje, w: Michał Głowiński, Aleksandra Okopień-Sławińska (red.), Przestrzeń i literatura, Ossolineum, Wrocław.

Adler Judith, 1989, Origins of Sightseeing, „Annales of Tourism Research”, t. 16, s. 7-29. Baudrillard Jean, 1998, Ameryka, tłum. Renata Lis, Sic!, Warszawa.

Bauman Zygmunt, 1998, Śmierć i nieśmiertelność. O wielości strategii życia, tłum. Norbert Leśniewski, Wydawnictwo Naukowe PWN, Warszawa.

Bauman Zygmunt, 2000, Ponowoczesność jako źródto cierpień, Sic!, Warszawa.

Benjamin Walter, 2006, Pasaże, tłum. Ireneusz Kania, Wydawnictwo Literackie, Kraków. Burszta Wojciech J., 2001, Kilka tez z zakresu iterologii, „Borussia. Kultura - Historia Literatura", nr 24/25.

Czerkawski Jan, 1992, Jana z Trzciany koncepcja godności cztowieka, w: Humanizm $i$ scholastyka. Studia z dziejów kultury filozoficznej w Polsce w XVI i XVII w., Wydawnictwo KUL, Lublin.

Davidson Rob, Cope Beulah, 2003, Turystyka biznesowa. Konferencje, podróże motywacyjne, wystawy, turystyka korporacyjna, tłum. Magdalena Karpiłowska, Delta, Warszawa.

Edensor Tim, 2001, Performing Tourism, Staging Tourism: (Re)producing Tourist Space and Practice, „Tourist Studies”, t. 1, s. 59-81.

Eriksen Thomas Hylland, 2003, Tyrania chwili, tłum. Grzegorz Sokół, PIW, Warszawa. Game Ann, 1991, Undoing the Social, Milton Keynes, Open University Press.

18 Uzyskane w ten sposób poczucie bezczasowości, tak pożądane przez zwolenników Slow Down, należy, przypomnę, do cech współczesnej kontemplacji/medytacji. 
Gibson James J., 1975, Events Are Perceivable but Time Is Not, w: Julius T. Fraser, Nathaniel M. Lawrence (red.), The Study of Time, Springer Verlag, New York.

Gleick James, 2003, Szybciej. Przyspieszenie niemal wszystkiego, tłum. Jacek Bieroń, Zysk i S-ka, Poznań.

Gurvitch George, 1969, La vocation actuelle de la socjologie, t. 2, PUF, Paris.

Hallowell Alfred Irving, 1955, Culture and Experience, University of Pennsylvania Press, Philadelphia.

Hodgkinson Tom, 2008, Jak być leniwym, tłum. Małgorzata Glasenapp, WAB, Warszawa.

Horton John, 1972, Time and Cool People, w: Larry A. Samovar, Richard E. Porter (red.), Intercultural Communication: A Reader, Wadsworth Publishing Company, Belmont, CA.

Hubert Henri, 1909, Étude sommaire de la répresentation du temps dans la religion et la magie, w: Henri Hubert, Marcell Mauss (red.), Mélanges d'histoire des religions, Alcan, Paris.

Illich Ivan, 1973, Tools of Conviviality, Harper and Row, New York.

Jacyno Małgorzata, 2007, Kultura indywidualizmu, Wydawnictwo Naukowe PWN, Warszawa.

Kamionka-Staszkowa Janina, 1992, Zbłąkany wędrowiec. Z dziejów romantycznej topiki, IBL PAN, Wrocław.

Kowalski Piotr, 2002, Odyseje nasze byle jakie. Droga, przestrzeń i podróżowanie w kulturze wspótczesnej, Alta2, Wrocław.

Lafarque Paul, 1961, Prawo do lenistwa, w: Pisma wyrane, t. 2, Książka i Wiedza, Warszawa.

Laskowska-Otwinowska Justyna, 2008, Globalne przeptywy kulturowe a obecność nowoosadników na wsi polskiej, Biblioteka MAiE w Łodzi, Łódź.

Laskowska-Otwinowska Justyna, 2009, Nowe sposoby zamieszkiwania na polskiej wsi wobec zjawisk w wybranych państwach, w: Tadeusz Bąk, Władysław Majkowski (red.), Kultura polska. Kierunki i dynamika zmian, Wydawnictwo UKSW, Warszawa.

Łyda Andrzej, 2005, Czas, przestrzeń, komunikacja, w: Janusz Arabski, Ewa Borkowska, Andrzej Łyda (red.), Czas w języku i kulturze, Wyższa Szkoła Zarządzania Marketingowego i Języków Obcych, Katowice.

MacCannell Dean, 2005, Turysta. Nowa teoria klasy próżniaczej, tłum. Ewa Klekot, Anna Wieczorkiewicz, Muza, Warszawa.

Maffesoli Michel, 2008, Czas plemion. Schylek indywidualizmu w spoteczeństwach ponowoczesnych, tłum. Marta Bucholc, Wydawnictwo Naukowe PWN, Warszawa.

Nieszczerzewska Małgorzata, 2006, Doświadczenie ruchu. Kobiety i nowoczesne miasto, w: Anna Zeidler-Janiszewska, Ryszard Nycz (red.), Nowoczesność jako doświadczenie, Universitas, Kraków.

Nietzsche Friedrich, 1905, Wiedza radosna, tłum. Leopold Staff, wyd. Jakub Mortkowicz, Warszawa.

Nowina-Sroczyńska Ewa, 2007, Uczty nomadów. Szkic do antropologii opowieści o Łodzi Kaliskiej, w: Miejsca biesiadne. Co o nich opowiada antropolog?, „Łódzkie Studia Etnograficzne", t. 46, Polskie Towarzystwo Ludoznawcze, Łódź.

Nowotny Helga, 1994, Time: The Modern and Postmodern Experience, Polity Press, Cambridge.

Otwinowska Barbara, 1980, Humanistyczna koncepcja otium $w$ Polsce na tle tradycji europejskiej, w: Zygmunt Skórzyński (red.), Studia porównawcze w literaturze staropolskiej, Ossolineum, Wrocław. 
Pańków Julia, 2009, Leniwa niedziela, „Gazeta Wyborcza”, 15 lutego, dodatek „Wysokie Obcasy", s. 44-47.

Pirsig Robert, 1999, Zen i sztuka obstugi motocykla, tłum. Tomasz Bieroń, Zysk i S-ka, Poznań.

Podemski Krysztof, 2004, Socjologia podróży, Wydawnictwo UAM, Poznań.

Prinke Rafal, 2007, Misterium tremendum: rytuat turystyki i duchowość New Age, w: Marek Kazimierczak (red.), Turystyka i podróżowanie w aksjologicznej perspektywie, Akademia Wychowania Fizycznego, Poznań.

Pullman Phillip, 2004, The War on Words, "Guardian Review", November, nr 6 (www.guardian.com/books/2004/nov/06/USA.politics).

Rojek Chris, 1985, Capitalism and Leisure Theory, Tavistock Publications, London-New York.

Schivelbusch Wolfgang, 1986, The Railway Journey: The Industrialization of Time and Space, University of California Press, Berkeley, CA.

Sommer Manfred, 2003, Zbieranie. Próba filozoficznego ujęcia, tłum. Jarosław Merecki, Oficyna Naukowa, Warszawa.

Steinbusch Michael, 2006, Miasto na wsi, w: Andrzej Kaleta, Gerd Vonderach (red.), Nowa socjologia wsi w Niemczech, Wydawnictwo UMK, Torun.

Stevenson Robert Louis, 1881, An Apology for Idlers, w: Virginibus Puerisque and Other Papers, Kegan Paul, London.

Tarkowska Elżbieta, 1987, Czas w spoteczeństwie. Problemy, tradycje, kierunki badań, Ossolineum, Wrocław.

Tarkowska Elżbieta, 2005, Zygmunt Bauman o czasie i procesach detemporalizacji, „Kultura i Społeczeństwo", nr 3.

Taylor John, 1994, A Dream of England: Landscape, Photography, And The Tourist's Imagination, Manchester University Press, Manchester-New York.

Turner Victor i Edith, 1978, Image and Pilgrimage in Christian Culture, Columbia University Press, New York.

Urry John, 1995, Consuming Places, Routledge, London-New York.

Urry John, 2008, Życie za kótkiem, tłum. Paulina Polak, w: Piotr Sztompka, Małgorzata Bogunia-Borowska (red.), Socjologia codzienności, Znak, Kraków.

Urry John, 2009, Socjologia mobilności, tłum. Janusz Stawiński, Wydawnictwo Naukowe PWN, Warszawa.

Venables Bernard, 1950, Mr. Crabtree Goes Fishing, London.

Vonderach Gerd, 2006, Nowe zagadnienia socjologii obszarów wiejskich, w: Andrzej Kaleta, Gerd Vonderach (red.), Nowa socjologia wsi w Niemczech, Wydawnictwo UMK, Toruń.

Wieczorkiewicz Anna, 1996, Wędrowcy fikcyjnych światów. Pielgrzym, rycerz, włóczęga, Wydawnictwo Naukowe S.A, Gdańsk.

Wilson Alexander, 1992, Culture of Nature, Blackwell Oxford.

Zeidler-Janiszewska Anna, 2006, Progi i granice doświadczenia (w) nowoczesności, w: Anna Zeidler-Janiszewska, Ryszard Nycz (red.), Nowoczesność jako doświadczenie, Universitas, Kraków.

www.slowmovement.com/life.php 
JOURNEYS TO WORK AS AN ELEMENT OF A NEW STYLE OF LIFE. THE POSTULATES OF THE "SLOW MOVEMENT"

Summary

Contestation of the cultural mainstream is the root of several new social phenomena within current euro-American civilization. One of them is the Slow Movement - a social movement calling for a slowing down of the pace of everyday life. The Movement's call for the protection of slow time has arisen from the fear of compression of time in the last decades of the XX century. One of the methods of protection proposed by Slow Movement is to view the business trip and journeys to work as a time for contemplation. This article aims to depict the phenomenon of travel connected to work as a factor of a change in lifestyle.

Key words/słowa kluczowe

style of life / styl życia; social movement / ruch społeczny; Slow Movement 